\title{
AN EVALUATION OF DIRECT IDENTIFICATION OF PATHOGENS FROM BLOOD CULTURES BY MALDI-TOF MASS SPECTROMETRY
}

\author{
Lina Savickaitė, Jelena Kopeykinienė \\ Klaipeda University Hospital, Lithuania
}

Key words: bloodstream infection, matrix-assisted laser desorption/ionization-time-of-flight mass spectrometry (MALDI-TOF MS).

\begin{abstract}
Summary
Rapid identification of the infecting organism may aid in choosing appropriate antimicrobial therapy. We used MALDI-TOF mass spectrometry to identify bacteria directly from the positive blood culture samples $(n=21) .85,71$ percent of these results was identified using of MALDI-TOF mass spectrometry. Identification time of bacteria directly from the blood culture takes more than 1 hour for 27,8 percent results.
\end{abstract}

\section{Introduction}

Accurate and fast diagnostic methods are necessary in order to be able to initiate correct treatment for bloodstream infection. Adequate empirical antibiotic therapy reduces the mortality rates in these patients $(1,2)$. Blood culture growing in automated systems allow bacteria to multiply, and usually takes a minimum of at least one day prior to the positive automated system signal about the levels of bacterial growth, and then a blood smear by Gram staining takes a few minutes, however, the mere microscopy results often do not provide sufficient information for the doctor to begin proper antibiotic therapy.

Recently, clinical microbiology laboratory of Klaipeda university hospital started to use sensitive, rapid and high-throughput identification method, matrix-assisted laser desorption/ionization-time-of-flight mass spectrometry (MALDI-TOF MS). It has been introduced in bacterial taxonomy and successfully applied to a number of taxa (39,11). MALDI-TOF mass spectrometry has the ability to measure peptides and other compounds in the presence of salts and to analyze complex peptide mixtures, making it an ideal method for measuring non-purified extracts and intact bacterial cells. Different experimental factors, including sample preparation, matrix solutions and organic solvents, affect the quality and reproducibility of bacterial MALDITOF mass spectrometry fingerprints (11-16). With a special set of MALDI Sepsityper is possible to identify bacteria directly from the positive blood culture (17-25). Most reports describe the blood culture must be grown in automated BACTEC system vials $(26,27)$. MALDI-TOF mass spectrometry has a high sensitivity and specificity (32).

Work objective: we investigated the direct identification of pathogens from the positive blood cultures using of MALDI-TOF mass spectrometry.

\section{Materials and methods}

The blood culture $8-10 \mathrm{ml}$ was collected in standart BD BACTEC Plus Aerobic/F and Plus Anaerobic/F vials for adults and 1-3 $\mathrm{ml}$ was collected in BD BACTEC Peds Plus/F vial for newborns. The automated system BD BACTEC Fx gives a signal if there is bacterial growth in each bottle.It is necessary to separate bacteria from the liquid culture media prior to detection by MALDI-TOF mass spectrometry. Removal of red blood cells and serum separation by centrifugation, and there after neutralization of bacteria using ethanol, precipitation and extraction, using formic acid and acetonitrile, must be done.Identification of microorganisms by MALDI-TOF mass spectrometry was rated by scores: range from 2,300 till 3,000 - highly probable species identification; 2,000 ... 2,299 - secure genus identification, probable species identification; $1,700 \ldots$ 1,999 - probable genus identification; $0,000 \ldots 1,699$ - not reliable identification.

\section{Results}

In all 494 blood culture samples, registered in clinical microbiology laboratory of Klaipeda university hospital from 2016 January 2nd till 2016 June 1st, 431 had negative results and $63(12,75 \%)$ had bacterial growth. $24(38,1 \%)$ blood culture samples had staphylococcal growth. MALDI Sepsityper was applied to $12(50 \%)$ of this growth and 9 
(75\%) was identified: 25 percent - Staphylococcus aureus; 8,33 percent - Staphylococcus epidermidis; 25 percent - Staphylococcus hominis; 8.333 percent - Staphylococcus haemolyticus; 8.333 percent Micrococcus luteus. 55,55 percent of staphylococcal growth was rated as secure genus identification, probable species identification and 44,44 percent of staphylococcal growth was rated as probable genus identification using of MALDI-TOF mass spectrometry.

See Table 1 for details.

All growing blood culture samples had only $11,11 \%$ of E. coli

Table 1.

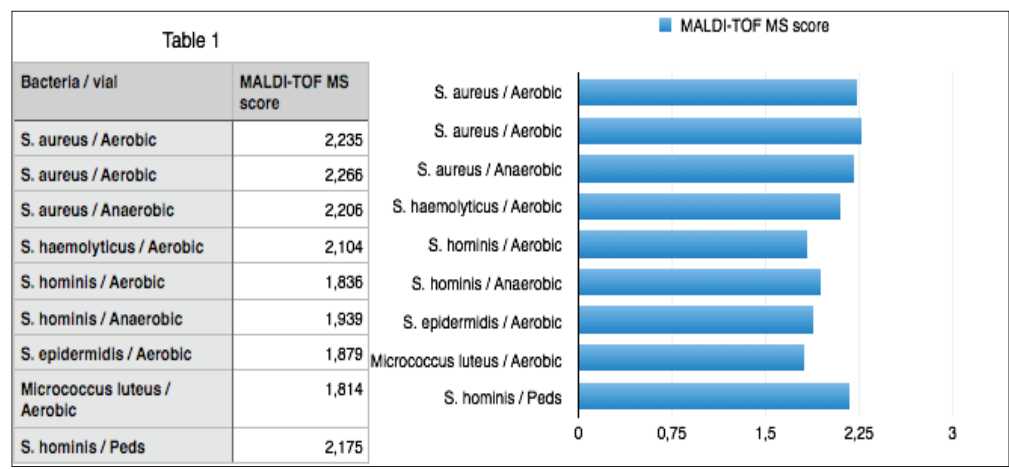

Table 2.

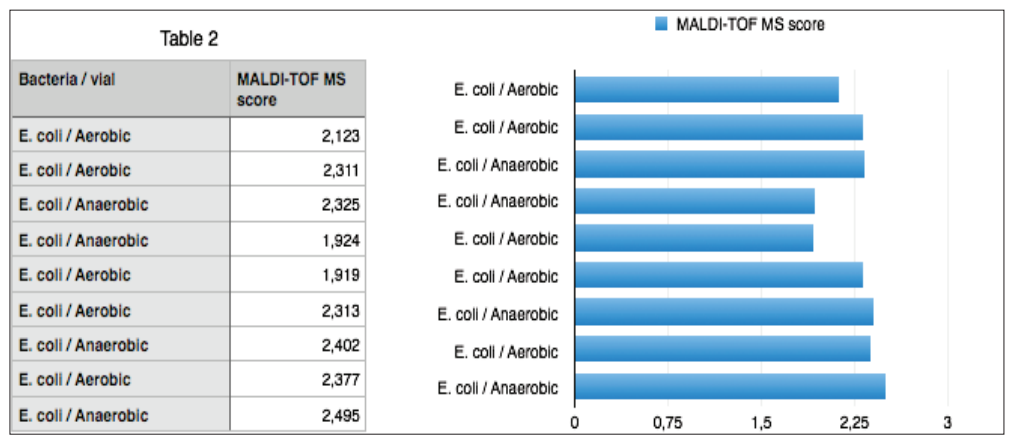

Table 3.

\begin{tabular}{|c|c|c|c|c|c|c|}
\hline \multicolumn{3}{|c|}{ Table 3} & \multicolumn{4}{|c|}{ BACTEC system signal time } \\
\hline Bacteria / vial & $\begin{array}{l}\text { BACTEC } \\
\text { system } \\
\text { signal time }\end{array}$ & $\begin{array}{l}\text { MALDI-TOF MS } \\
\text { Identification } \\
\text { time }\end{array}$ & \multirow{7}{*}{\begin{tabular}{r|r} 
& E. coll / Aeroblc \\
1 & E. coll / Aerobic / Anaerobic \\
5 & E. coll / Anaerobic \\
5 & E. coll / Aerobic \\
5 & E. coll / Aerobic / Anaerobic \\
1 & E. coll / Aerobic / Anaerobic
\end{tabular}} & 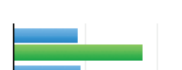 & \\
\hline E. coll / Aerobic & $8: 05$ & 10:11 & & & & \\
\hline E. coll / Aerobic/ / Anaerobic & $8: 10$ & $12: 05$ & & $\bar{z}$ & & \\
\hline E. coll / Anaerobic & $8: 15$ & 12:05 & & 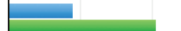 & & \\
\hline E. coll / Aerobic & $8: 05$ & $10: 45$ & & 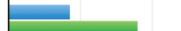 & & \\
\hline E. coll / Aerobic / Anaerobic & $8: 00$ & 10:11 & & $\nabla$ & & \\
\hline E. coll / Aerobic / Anaerobic & $8: 10$ & 9:51 & & & & \\
\hline $\begin{array}{l}\text { S. hominis / Aerobic/ } \\
\text { Anaerobic }\end{array}$ & $8: 10$ & 11:19 & ${ }_{9}^{1}$ S. hominis / Aerobic / Anaerobic & & & \\
\hline Micrococcus luteus / Aeroblc & 13:25 & 14:59 & \multirow{2}{*}{$\begin{array}{l}\text { Micrococcus luteus / Aerobic } \\
\text { S. epidermidis / Aerobic } \\
\text { S. aurues / Aerobic }\end{array}$} & 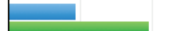 & & \\
\hline S. epidermidis / Aerobic & $8: 10$ & 10:31 & & $\square$ & & \\
\hline S. aurues / Aerobic & $8: 00$ & 11:25 & \multirow{3}{*}{$\begin{array}{l}\text { S. aurues / Aerobic / Anaeroblc } \\
\text { S. nominis / Peds } \\
\text { S. naemolyticus / Aeroblc }\end{array}$} & $\square$ & & \\
\hline $\begin{array}{l}\text { S. aurues / Aerobic/ } \\
\text { Anaerobic }\end{array}$ & 8.05 & 12:50 & & & & \\
\hline S. hominis / Peds & $8: 05$ & 11:39 & & 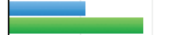 & & \\
\hline S. haemolyticus / Aerobic & $8: 30$ & 10:21 & & $10: 37$ & $12: 56$ & $15: 15$ \\
\hline
\end{tabular}

growth. MALDI Sepsityper was applied to 9 $(85,71 \%)$ blood culture samples of this growth and all was identified. 66,66 percent of $E$. coli was rated as highly probable species identification, 11,11 percent - as secure genus identification, probable species identification and 22,22 percent - as probable genus identification using of MALDI-TOF mass spectrometry. See Table 2 for details.

In this study using of MALDI-TOF mass spectrometry as highly probable species identification we had only for $E$. coli growth $(33,33 \%)$, as secure genus identification, probable species identification - less for $E$. coli $(5,55 \%)$ and more - for staphylococcal $(27,77 \%)$ growth, as probable genus identification - less for E. coli $(11,11 \%)$ and more for staphylococcal $(22,22 \%)$ growth $(\mathrm{r}=0,616$, $\mathrm{p}=0,006)$. Of all identified $(\mathrm{n}=18)$ blood culture samples 50 percent had $E$. coli growth, 27,8 percent had plasma negative staphylococcal growth and 16,7 percent had Staphylococcus aureus growth. The most growing BACTEC vials - Aerobic $(61,1 \%)$.

Time taken to identify staphylococcal and E.coli growth, of fixed automated system BD BACTEC Fx signal time to MALDI-TOF mass spectrometry identification time, is mostly more than 3 hours (44,4\%). 27,8 percent takes more than 1 hour, 22,2 percent - more than 2 hour, and less, 5,6 percent takes more than 4 hours. See Table 3 for details.

\section{Discussion}

Any way traditional pathogen identification from blood culture takes more than 24 hours and so is not able to guide early choice of antimicrobial therapy in sepsis patients.

Identification of microorganisms from positive blood culture using of MALDI Sepsity per processing kit requires approximately 20 minutes and it does independent of species $(6,10,13,18,20,25,26,32,33)$. Batch processing added approximately $1 \mathrm{~min}$ per blood culture analyzed.Our estimated time to identify bacteria from the positive blood culture, of fixed automated system BD BACTEC Fx signal time to MALDI-TOF mass spectrometry identification time, is not an objective, it includes the blood smear preparation time by Gram staining, 
as well as organizational reasons of most microbiological laboratories to perform the method in batches. But in comparison with other studies our estimated time correspond to with foreign laboratories (10). Some studies even describe MALDI-TOF mass spectrometry advantages compared to other direct methods to identify the bacteria from the blood, for example, using polymerase chain reaction and the latter method is limited by the high cost, not every species of microorganisms is determined in one study, in addition, it is enough difficult to realize in practic (28-31).

\section{Conclusion}

In conclusion, the exact bacteria identification from the positive blood culture using of MALDI-TOF mass spectrometry and presentation to the doctor allows to start adequate empirical antibiotic therapy in less time.

\section{References}

1. Kumar A, Ellis P, Arabi Y, Roberts D, Light B, Parrillo JE, Dodek P, Wood G, Kumar A, Simon D, Peters C, Ahsan M, Chateau D. Cooperative antimicrobial therapy of septic shock database research group initiation of inappropriate antimicrobial therapy results in a fivefold reduction of survival in human septic shock. Chest 2009; 136 (5): 1237-1248.

http://dx.doi.org/10.1378/chest.09-0087

2. Kumar A, Roberts D, Wood KE, Light B, Parrillo JE, Sharma S, Suppes R, Feinstein D, Zanotti S, Taiberg L, Gurka D, Kumar A, Cheang M. Duration of hypotension before initiation of effective antimicrobial therapy is the critical determinant of survival in human septic shock. Crit Care Med 2006; 34 (6): 1589-1596.

http://dx.doi.org/10.1097/01.CCM.0000217961.75225.E9

3. Fenselau, C., Demirev, P.A. Characterization of intact microorganisms by MALDI mass spectrometry. Mass Spectrom 2001; 20 (4): 157-171.

http://dx.doi.org/10.1002/mas.10004

4. Lay JO, Jr, Liyanage R. MALDI-TOF Mass Spectrometry of intact bacteria. In: Wilkins CL, Lay JO, Jr. (Eds.), Identification of microorganisms by mass spectrometry, John Willey \& Sons, Hoboken NJ. 2006; 352.

http://dx.doi.org/10.1002/0471748641.ch6

5. Van Baar BL. Characterisation of bacteria by matrix-assisted laser desorption/ionization and electrospray mass spectrometry. FEMS Microbial 2000; 24: 193-219.

http://dx.doi.org/10.1016/S0168-6445(99)00036-4

6. Barbuddhe SB, Maier T, Schwarz G, Kostrzewa M, Holf H, Domann E, Chakraborty T, Hain T. Rapid identification and typing of listeria species by matrix-assisted laser desorption ionization-time of flight mass spectrometry. Appl. Environ. Microbiol 2008; 74(17): 5402-5407.

7. Fagerquist CK, Yee E, Miller, WG. Composite sequence prote- omic analysis of protein biomarkers of Campylobacter coli, C. lari and C. concisus for bacterial identification. Analyst 2007; 132(10): 1010-1023.

http://dx.doi.org/10.1039/b702859h

8. Grosse-Herrenthey A, Maier T, Gesseler F, Schaumann R, Böhnel H, Kostrzewa M, Krüger M. Challenging the problem of clostridial identification with matrix-assisted laser desorption and ionization-time-of-flight mass spectrometry (MALDI-TOF MS). Anaerobe 2008; 14(4): 242-249.

http://dx.doi.org/10.1016/j.anaerobe.2008.06.002

9. Moura H, Woolfitt AR, Carvalho MG, Pavlopoulos A, Teixeira LM, Satten GA, Barr JR. MALDI-TOF mass spectrometry as a tool for differentiation of invasive and noninvasive Streptococcus pyogenes isolates. FEMS Immunol. Med. Microbiol 2008; 53 (3): 333-342.

http://dx.doi.org/10.1111/j.1574-695X.2008.00428.x

10. Idelevich EA, Schüle I, Grünastel B, Wüllenweber J, Peters G, Becker K. Rapid identification of microorganisms from positive blood cultures by MALDI-TOF mass spectrometry subsequent to very short-term incubation on solid medium. Clinical Microbiology and Infection 2014; 20 (10): 1001-1006. http://dx.doi.org/10.1111/1469-0691.12640

11. Vargha M, Takats Z, Konopka A, Nakatsu CH. Optimization of MALDI-TOF MS for strain level differentiation of Arthrobacter isolates. J. Microbiol. Methods 2006; 66: 399-409.

http://dx.doi.org/10.1016/j.mimet.2006.01.006

12. Jaskolla TW, Karas M, Roth U, Steinert K, Menzel C, Reihs K. Comparison between vacuum sublimed matrices and conventional dried droplet preparation in MALDI-TOF mass spectrometry. J. Am. Soc. Mass Spectrom 2009; 20 (6): 1104-1114. http://dx.doi.org/10.1016/j.jasms.2009.02.010

13. Ruelle V, El Moualij B, Zorzi W, Ledent P, Pauw ED. Rapid identification of environmental bacterial strains by matrixassisted laser desorption/ionization time-of-flight mass spectrometry. Rapid Commun. Mass Spectrom 2004; 18 (18): 2013-2019.

http://dx.doi.org/10.1002/rcm.1584

14. Smole SC, King LA, Leopold PE, Arbeit RD. Sample preparation of Gram-positive bacteria for identification by matrix assisted laser desorption/ionization time-of-flight. J. Microbiol. Methods 2002; 48 (3): 107-115.

http://dx.doi.org/10.1016/S0167-7012(01)00315-3

15. Williams TL, Andrzejewski D, Lay JO, Musser SM. Experimental factors affecting the quality and reproducibility of MALDI TOF mass spectra obtained from whole bacteria cells. J. Am. Soc. Mass Spectrom 2003; 14 (4): 342-351.

http://dx.doi.org/10.1016/S1044-0305(03)00065-5

16. De Bruyne K, Slabbinck B, Waegeman W, Vauterin P, De Baets $B$, Vandamme P. Bacterial species identification from MALDITOF mass spectra through data analysis and machine learning. Systematic and Applied Microbiology 2011; 34: 20-29. 
http://dx.doi.org/10.1016/j.syapm.2010.11.003

17. Veen SQ, Claas EC, Kuijper EJ. High-throughput identification of bacteria and yeast by matrix-assisted laser desorption ionization-time of flight mass spectrometry in conventional medical microbiology laboratories. J Clin Microbiol 2010; 48 (3): 900-907.

http://dx.doi.org/10.1128/JCM.02071-09

18. Sogawa K, Watanabe M, Sato K, Segawa S, Ishii C, Miyabe A, Murata S, Saito T, Nomura F. Use of the MALDI BioTyper system with MALDI-TOF mass spectrometry for rapid identification of microorganisms. Anal Bioanal Chem 2011; 400 (7): 1905-1911.

http://dx.doi.org/10.1007/s00216-011-4877-7

19. Bizzini A, Jaton K, Romo D, Bille J, Prod'hom G, Greub G. Matrix-assisted laser desorption ionization-time of flight mass spectrometry as an alternative to $16 \mathrm{~S}$ rRNA gene sequencing for identification of difficult-to-identify bacterial strains. J Clin Microbiol 2011; 49 (2): 693-696.

http://dx.doi.org/10.1128/JCM.01463-10

20. Stevenson LG, Drake SK, Murray PR. Rapid identification of bacteria in positive blood culture broths by matrix-assisted laser desorption ionization-time of flight mass spectrometry. J Clin Microbiol 2010; 48 (2): 444-447.

http://dx.doi.org/10.1128/JCM.01541-09

21. Ferreira L, Sánchez-Juanes F, Porras-Guerra I, García-García MI, García-Sánchez JE, González-Buitrago JM, Mu-oz-Bellido JL. Microorganisms direct identification from blood culture by matrix-assisted laser desorption/ionization time-of-flight mass spectrometry. Clin Microbiol Infect 2011; 17 (4): 546-551.

http://dx.doi.org/10.1111/j.1469-0691.2010.03257.x

22. Scola B, Raoult D. Direct identification of bacteria in positive blood culture bottles by matrix-assisted laser desorption ionization time-of-flight mass spectrometry. PLoS One 2009; 4 (11): 8041.

http://dx.doi.org/10.1371/journal.pone.0008041

23. Prod'hom G, Bizzini A, Durussel C, Bille J, Greub G. Matrix-assisted laser desorption ionization-time of flight mass spectrometry for direct bacterial identification from positive blood culture pellets. J Clin Microbiol 2010; 48 (4): 1481-1483. http://dx.doi.org/10.1128/JCM.01780-09

24. Moussaoui W, Jaulhac B, Hoffmann AM, Ludes B, Kostrzewa M, Riegel P, Prévost G. Matrix-assisted laser desorption ionization time-of-flight mass spectrometry identifies $90 \%$ of bacteria directly from blood culture vials. Clin Microbiol Infect 2010; 16 (11): 1631-1638.

http://dx.doi.org/10.1111/j.1469-0691.2010.03356.x

25. Christner M, Rohde H, Wolters M, Sobottka I, Wegscheider K, Aepfelbacher M. Rapid identification of bacteria from positive blood culture bottles by use of matrix-assisted laser desorptionionization time of flight mass spectrometry fingerprinting. J Clin Microbiol 2010; 48 (5): 1584-1591.
http://dx.doi.org/10.1128/JCM.01831-09

26. Ferroni A, Suarez S, Beretti JL, Dauphin B, Bille E, Meyer J, Bougnoux ME, Alanio A, Berche P, Nassif X. Real-time identification of bacteria and Candida species in positive blood culture broths by matrix-assisted laser desorption ionizationtime of flight mass spectrometry. J Clin Microbiol 2010; 48 (5): 1542-1548.

http://dx.doi.org/10.1128/JCM.02485-09

27. Szabados F, Michels M, Kaase M, Gatermann S. The sensitivity of direct identification from positive BacT/ALERT ${ }^{\mathrm{TM}}$ (bioMérieux) blood culture bottles by matrix-assisted laser desorption ionization time-of-flight mass spectrometry is low. Clin Microbiol Infect 2011; 17 (2): 192-195.

http://dx.doi.org/10.1111/j.1469-0691.2010.03229.x

28. Peters RP, Agtmael MA, Simoons-Smit AM, Danner SA, Vandenbroucke-Grauls CM, Savelkoul PH. Rapid identification of pathogens in blood cultures with a modified fluorescence in situ hybridization assay. J Clin Microbiol 2006; 44 (11): 4186-4188. http://dx.doi.org/10.1128/JCM.01085-06

29. Loonen AJ, Jansz AR, Kreeftenberg H, Bruggeman CA, Wolffs PF, Brule AJ. Acceleration of the direct identification of Staphylococcus aureus versus coagulase-negative staphylococci from blood culture material: a comparison of six bacterial DNA extraction methods. Eur J Clin Microbiol Infect Dis 2011; 30 (3): 337-342.

http://dx.doi.org/10.1007/s10096-010-1090-0

30. Wallet F, Nseir S, Baumann L, Herwegh S, Sendid B, Boulo M, Roussel-Delvallez M, Durocher AV, Courcol RJ. Preliminary clinical study using a multiplex real-time PCR test for the detection of bacterial and fungal DNA directly in blood. Clin Microbiol Infect 2010; 16 (6): 774-779.

http://dx.doi.org/10.1111/j.1469-0691.2009.02940.x

31. Wellinghausen N, Kochem AJ, Disqué C, Mühl H, Gebert S, Winter J, Matten J, Sakka SG. Diagnosis of bacteremia in whole-blood samples by use of a commercial universal $16 \mathrm{~S}$ rRNA gene-based PCR and sequence analysis. J Clin Microbiol 2009; 47 (9): 2759-2765.

http://dx.doi.org/10.1128/JCM.00567-09

32. Egli A, Osthoff M, Goldenberger D, Halter J, Schaub S, Steiger J, Weisser M, Frei R. Matrix-assisted laser desorption/ionization time-of-flight mass spectrometry (MALDI-TOF) directly from positive blood culture flasks allows rapid identification of blood stream infections in immunosuppressed hosts. Transpl Infect Dis 2015; 17 (3): 481-487.

http://dx.doi.org/10.1111/tid.12373

33. Loonen AJM, Jansz AR, Stalpers J, Wolffs PFG and van den Brule AJC. An evaluation of three processing methods and the effect of reduced culture times for faster direct identification of pathogens from BacT/ALERT blood cultures by MALDI-TOF MS. Eur J Clin Microbiol Infect Dis 2012; 31 (7): 1575-1583. http://dx.doi.org/10.1007/s10096-011-1480-y 
TIESIOGINĖS BAKTERIJŲ IDENTIFIKACIJOS IŠ KRAUJO PASĖLIO IVERTINIMAS PANAUDOJANT MALDI-TOF MASIŲ SPEKTROMETRIJĄ

\section{Savickaitė, J. Kopeykinienè}

Raktažodžiai: kraujo infekcijos, MALDI-TOF masių spektrometrija (MALDI-TOF MS).

Santrauka

Greitas infekcijos nustatymas organizme gali padèti pasirinkti tinkamą antimikrobinį gydymą. Tikslūs ir greiti diagnostikos metodai yra ypač aktualūs nustatant kraujo infekcijos sukèlèjus, o paskirta adekvati antibiotikų terapija sumažina mirtingumo rodiklius. Todèl panaudojant MALDI-TOF masių spektrometriją bandème nustatyti bakterijas tiesiogiai iš teigiamų kraujo pasèlio mèginių $(n=21)$. Iš jų 85,71 proc. buvo identifikuoti panaudojant MALDI-TOF masių spektrometriją. Bakterijų identifikavimo laikas tiesiogiai iš kraujo kultūros užima daugiau nei 1 valandą 27,8 proc. rezultatų, daugiau nei 2 val. - 22,2 proc. rezultatų, daugiausiai rezultatų, daugiau nei 3 val. $-44,4$ proc. ir mažiausiai rezultatų, daugiau nei 4 val. $-5,6$ proc.

Adresas susirašinèti: savickaitelinute@yahoo.com

Gauta 2016-11-01 